\title{
A HPLC method with UV detection for analysing of 2,6-diaminopimelic acid in rumen bacteria and intestinal digesta
}

\author{
M. Czauderna and J. Kowalczyk \\ The Kielanowski Institute of Animal Physiology and Nutrition, \\ Polish Academy of Sciences \\ 05-110 Jabtonna, Poland
}

(Received 25 March 2002; accepted 9 May 2002)

\begin{abstract}
A HPLC method with UV detection for quantification of 2,6-diaminopimelic acid (DAPA) in rumen bacteria, duodenal and ileal digesta and faeces is described. Biological samples were hydrolyzed with $6 \mathrm{M} \mathrm{HCl}$ for $20 \mathrm{~h}$ at $104 \pm 2^{\circ} \mathrm{C}$. DAPA was separated after pre-column derivatization with o-phthaldialdehyde (OPA) in the presence of ethanethiol (ESH). DAPA derivative was analyzed using a reversed-phase $C_{18}$ column $(3 \mu \mathrm{m}, 250 \times 2.1 \mathrm{~mm}$, L.D.) by a gradient elution program and the UV and fluorescence detections. The converted DAPA (as two peaks) was UV monitored at 230.7 and $337 \mathrm{~nm}$ (the retention times: $46.77 \pm 0.20$ and $47.25 \pm 0.21 \mathrm{~min}$ ). The total run time, including $10 \mathrm{~min}$ of the column re-equilibration, was $60 \mathrm{~min}$. The average recoveries of DAPA standards added to biological samples were satisfactory: $99.32 \pm 3.78$ and $99.00 \pm 4.25 \%$ with UV detections at 230.7 and $337 \mathrm{~nm}$, respectively. The presented HPLC method with the UV detections at 230.7 and $337 \mathrm{~nm}$ offers the low intra- and inter-assay coefficient variations (ca 0.5 and $\mathrm{ca} 1.1 \%$ ), high recoveries $(\sim 100 \%)$, so this procedure gives satisfactory precision, reproducibility and accuracy. The use of the UV detection at $337 \mathrm{~nm}$ offers lower limits of detection (ca $0.28 \mathrm{nmol} / \mathrm{ml}$ ) and quantification (ca $0.91 \mathrm{nmol} / \mathrm{ml}$ ) than the UV monitoring at $230.7 \mathrm{~nm}$ and the fluorescence detection (ca 1.1 and ca $3.6 \mathrm{nmol} / \mathrm{ml}$, respectively). However, UV measurements at $230.7 \mathrm{~nm}$ produced strongest signals as compared with UV signals at $337 \mathrm{~nm}$ and the fluorescence detections. The presented HPLC method with UV at $230.7 \mathrm{~nm}$ enabled quantified of DAPA as a largest signal, so, this HPLC mode can be applied for the estimation of ruminal bacterial protein supply to ruminants and for monitoring of bacterial contamination of examined materials.
\end{abstract}

KEY WORDS: 2,6-diaminopimelic acid, indirect marker, UV detection, HPLC 


\section{INTRODUCTION}

The peptidoglycan layer of the most bacterial cell walls contains the unique amino acid, 2,6-diaminopimelic acid (DAPA), which can exist as a mixture of diastereomeric forms (i.e. DD, LL and meso forms) (Ling et al., 1990; Masson et al., 1991; El-Waziry and Onodera, 1996). Therefore, because of DAPA apparent uniqueness to bacteria - it is not found in the plant or animal tissues - this amino acid has been used to study bacterial cell wall biosynthesis (Masson et al., 1991; El-Waziry and Onodera, 1996; El-Waziry et al., 1996), to classify bacteria taxonomically (Nagasawa et al., 1993), degradation (Philipczyk et al., 1996) and as a indirect marker for the measurement of bacterial contamination in biological materials (Puchała et al., 1992). Although bacterial cell walls are structurally diverse, the DAPA/protein ratio is relatively constant in bacterial cells, therefore, DAPA can been used as a specific indicator of bacterial biomass concentration in digestive tracts contents of ruminants (Czerkawski, 1974; Robinson et al., 1996; Djouvinow and Todorov, 1998; Zhao et al., 1998). To advance our studies of bacterial grow within the rumen microbial ecosystem, we required a simple and less costly method for the rapid, reproducible, specific and sensitive determining DAPA in rumen bacteria, duodenum and ileum contents, as well as in faeces samples. The traditional analytical method applied to determination of DAPA in biological samples is ion-exchange chromatography (IEC) followed by reaction with ninhydryn (Cockburn and Williams, 1984; Edols, 1985; Volker et al., 1991). IEC method is suitable for routine quantification of DAPA, however, the analysis time is long, has a rather pour detection limits and requires costly dedicated systems. On the other hand, Czerkawski (1974) offers a cheaper method for DAPA quantitate, unfortunately, this procedure is labour intensive, requires many transfer steps and is susceptible to interference from proline (Webster et al., 1990; Puchała et al., 1992). Quantification of DAPA by HPLC methods may overcome of above mentioned difficulties (Czauderna and Kowalczyk, 1999; Czauderna et al., 1999). However, HPLC methods for DAPA determining in digesta or rumen fluids requires costly purifications of samples (Webster et al., 1990) or individual sample running gradient programs as well as fractionation of DAPA from other amino acids and endogens species is unsatisfactory (Buck and Krummen, 1987; Mengin-Lecreulx et al., 1988; Webster et al., 1990; Puchała et al., 1992; ElWaziry et al., 1996; Philipczyk et al., 1996; McKerrow et al., 2000). Therefore, we develop the method based on reversed-phase HPLC in combination with $o$-phthaldialdehyde (OPA) derivatization. We suggested that satisfactory specificity and sensitivity of DAPA assays can be achieved using a high-resolution long $\mathrm{C}_{18}$ column and high-efficiently, however, not specific UV detection. 


\section{MATERIAL AND METHODS}

\section{Reagents}

All chemicals were of analytical grade; organic solvents were of HPLC grade. Acetonitrile, methanol were purchased from POCh (Poland). Ethanethiol (ESH) was obtained from Aldrich (Germany), while $o$-phthaldialdehyde (OPA) and DL 2,6-diaminopimelic acid (DAPA) (a mixture of LL, DD and meso diastereomers) from Sigma (USA). The amino acids protein hydrolysate standard kit was obtained from Waters Corporation (AccQ-Tag ${ }^{\text {TM }}$, Part No. WATO52875, USA). Water used for the preparation of mobile phases and chemical reagents was prepared using an Elix $^{\mathrm{TM}}$ water purification system (Millipore). The mobile phases were filtered through a $0.45 \mu \mathrm{m}$ membrane filter (Millipore).

\section{Chromatographic equipment}

An Alliance separation module (model 2690, Waters) with a Waters 996 photodiode array detector (DAD) and a Waters 474 fluorescence detector was used for elution system. The OPA derivatives were monitored using the fluorescence or UV detector. DAD was operated in a UV range from 195 to $450 \mathrm{~nm}$ with a spectral resolution of $1.2 \mathrm{~nm}$ and a measurement frequency of 1 spectrum per second. Development of the analytical method, collection and data integration were performed using Millennium 2001 software (version 2.15) and a Pentium III computer (Compaq). The analytical column used was a $\mathrm{C}_{18}$ column $(3 \mu \mathrm{m}, 250 \times 2.1 \mathrm{~mm}$ I.D., CPI, USA) in conjunction with a guard column (Waters) of $10 \times 6 \mathrm{~mm}$ containing reversed phase $\mathrm{C}_{18}(30-40 \mu \mathrm{m})$ pellicular packing material.

Analvtical mobile phases and the gradient elution system

A gradient elution program (Table 1) was used for DAPA assays in biological samples. The following elution mobile phases were used: solvent A was acetonitrilebuffer $(4: 23 \mathrm{v} / \mathrm{v})$. The buffer for mobile phase A was prepared from $0.02 \mathrm{M}$ $\mathrm{Na}_{2} \mathrm{HPO}_{4}$ adjusted to $\mathrm{pH} 6.4$ with $\sim 30 \%$ phosphoric acid. Solvent B was acetonitrile-methanol-water $(30: 30: 40, \mathrm{v} / \mathrm{v} / \mathrm{v})$. The maximum system pressure was $35.00 \pm 0.14 \mathrm{MPa}$, while the minimal one was $27.47 \pm 0.09 \mathrm{MPa}$. Injection volumes were 5-25 $\mu \mathrm{l}$. The limits of detection (LOD) was calculated at a signal-to-background ratio of 3 , while the limit of quantification (LOQ) was defined as 10 times the background under a peak (Meyer, 1999). 
TABLE 1

Gradient elution program (column temperature: $30^{\circ} \mathrm{C}$ )

\begin{tabular}{|c|c|c|c|c|}
\hline \multirow{2}{*}{$\begin{array}{l}\text { Time } \\
\text { min }\end{array}$} & \multirow{2}{*}{$\begin{array}{l}\text { Flow-rate } \\
\text { ml min }\end{array}$} & \multicolumn{3}{|r|}{ Composition, \% } \\
\hline & & Solvent A & & Solvent B \\
\hline 0 & 0.26 & 100 & 0 & \\
\hline 0.5 & 0.27 & 100 & 0 & (linearly increased from $0 \mathrm{~min}$ ) \\
\hline 1.0 & 0.30 & 100 & 0 & (linearly increased from $0.5 \mathrm{~min}$ ) \\
\hline 6.0 & 0.30 & 80 & 20 & (linearly increased from $1 \mathrm{~min}$ ) \\
\hline 12.5 & 0.30 & 78 & 22 & (linearly increased from $6 \mathrm{~min}$ ) \\
\hline 18.0 & 0.30 & 60 & 40 & (linearly increased from $12.5 \mathrm{~min}$ ) \\
\hline 28.0 & 0.30 & 40 & 60 & (linearly increased from $22 \mathrm{~min}$ ) \\
\hline 40.0 & 0.29 & 25 & 75 & (lincarly increased from $28 \mathrm{~min}$ ) \\
\hline 45.0 & 0.29 & 10 & 90 & (linearly increased from $40 \mathrm{~min}$ ) \\
\hline 45.2 & 0.29 & 0 & 100 & (linearly increased from $45 \mathrm{~min}$ ) \\
\hline $50.1^{\mathrm{a}}$ & 0.29 & 100 & 0 & (linearly decreased from $50 \mathrm{~min}$ ) \\
\hline
\end{tabular}

${ }^{\mathrm{a}}$ - after $50.1 \mathrm{~min}$ the column were re-equilibrated for $10 \mathrm{~min}$ in $100 \%$ solvent $\mathrm{A}$ at a flow-rate of $0.29 \mathrm{ml} / \mathrm{min}$

Preparation of the borate buffer

Boric acid, $2.473 \mathrm{~g}$, was dissolved in $80 \mathrm{ml}$ of HPLC grade water and the $\mathrm{pH}$ adjusted to 9.8-9.9 with 4-5 $\mathrm{M} \mathrm{KOH}$. The resulting solution was filtered through filter paper and then diluted to a total volume of $100 \mathrm{ml}$ to make $0.4 \mathrm{M}$ borate buffer.

Preparation of derivatizing reagent (OPA/ESH)

Seventy-five mg of OPA were dissolved in $4.5 \mathrm{ml}$ of HPLC grade methanol and $0.5 \mathrm{ml}$ borate buffer. Next, $70 \mu \mathrm{l}$ of ESH were added and the resulting solution was mixed. It is recommended to protect the derivatizing reagent from light and to store refrigerated $\left(-18^{\circ} \mathrm{C}\right)$ when not in use. The reagent strength was maintained by addition of $10 \mu \mathrm{l}$ of ESH every 2 days.

\section{Preparation and hydrolysis of biological samples}

Sample of rumen bacteria (Lachnospira multiparus 685), ovine duodenal, ileal digesta and faeces were frozen, lyophilized and the obtained homogeneous materials (about $200 \mathrm{mg}$ ) hydrolyzed with $25 \mathrm{ml}$ of $6 \mathrm{M} \mathrm{HCl}$ at $104 \pm 2^{\circ} \mathrm{C}$ for $20 \mathrm{~h}$ in sealed tubes. After cooling the hydrolysates were filtered through filter paper and washed two times with deionized water. Hydrochloric acid was removed from the filtrates in a vacuum rotary evaporator. Twenty $\mathrm{ml}$ of deionized water were added 
to the residues and then evaporated to dryness again in vacuum to remove residues of $\mathrm{HCl}$. This washing procedure was repeated three times. The hydrolyzates were stored at $-18^{\circ} \mathrm{C}$ until analyzed. The residue was redissolved in $1.5 \mathrm{ml}$ of the borate buffer $(\mathrm{pH}$ 9.8-9.9) and then used for the derivatization as below.

\section{Derivatization procedure}

To an autosampler reacti-vial $50 \mu \mathrm{l}$ of redissolved biological sample, $1 \mathrm{ml}$ of OPA/ESH derivatizing reagent and $10 \mu \mathrm{l}$ of $1 \mathrm{M} \mathrm{NaOH}$ were added. The contents were mixed and reacted for $3 \mathrm{~min}$ at room temperature. It is recommended to protect processed samples from the light. At the end of the 3 min of derivatization time, the processed samples were injected onto the column. The derivatizing process for amino acids standards of protein hydrolysate and DAPA was the same as for biological samples.

\section{RESULTS AND DISCUSSION}

The main disadvantage of chromatographic determination of underivatized DAPA was that this amino acid had relatively high molar absorption only in the short UV wavelengths range $(\lambda<200 \mathrm{~nm})$, in which many suitable mobile phase components are not transparent. Therefore, DAPA was converted with OPA to a highly fluorescent derivative containing a very high band in the UV spectral range from 210 to $250 \mathrm{~nm}$ and a weaker one from 300 to $380 \mathrm{~nm}$ (El-Shazly and Hungate, 1966; Hill et al., 1979; Rattenbury, 1981; Cooper et al., 1984; Lindroth et al., 1985; Sarwar and Botting, 1993; Czauderna and Kowalczyk, 1999; Czauderna et al., 1999). Detailed investigation of various solvent mixtures showed that the need for quaternary solvent mixtures and the high-resolution and long $\mathrm{C}_{18}$ column was well substantiated. Really, derivatized DAPA possess relatively high absorbance at $230.7 \mathrm{~nm}$ (Hill et al., 1979; Czauderna and Kowalczyk, 1999), therefore, the derivatized DAPA diastereomers eluted as pair of peaks (at $46.77 \pm 0.20$ and $47.25 \pm 0.21 \mathrm{~min}$ ) can be clearly distinct from all endogenous species present in all assayed biological samples. Moreover, after 45.2 min of elution run, the used clution system was found to provide excellent low baseline level from the left and right side of the analytical DAPA peaks, when the UV detection was used. DAPA peaks were identified on the basis of the retention time of processed DAPA standards injected separately and by adding standard solutions to biological samples. Obviously, DAPA peaks were differentiated from unidentified species by use of the photodiode detector. As expected, all DAPA peaks were absent from the blank, when the presented HPLC system was used. Based on our earlier studies (Czauderna et al., 1999; Czauderna and Kowalczyk, 1999) and the work of other authors (El-Shazly and Hungate, 
1966; Webster et al., 1990; Nagasawa et al., 1993; El-Waziry and Onodera, 1996) it can be concluded that the smaller DAPA peak (peak 1) is a mixture of DD and LL diastereomers, while the larger one (peak 2) is a meso DAPA diastereomer.

Considering absorbance spectra of DAPA derivatives obtained by the diode array detector it can be suggested that the UV and fluorescence detections obtained by the use of $\sim 231 \mathrm{~nm}$ wavelength produced greater signals in comparison with UV and fluorescence signals obtained using $337 \mathrm{~nm}$ wavelength (Hill et al., 1979; Czauderna and Kowalczyk, 1999). Thus, attempts were made to compare the results of DAPA quantification as dependent upon used the wavelength and the detection mode. Table 2 gives a comparison of responses of fluorescence detector and DAD obtained by the use of the $\sim 231$ and $337 \mathrm{~nm}$ wavelength. As expected, both excitation at $231 \mathrm{~nm}$ and UV monitoring at $230.7 \mathrm{~nm}$ produced considerably greater responses of both detectors as compared with excitation and UV detection at $337 \mathrm{~nm}$. Moreover, Table 2 summarized still other results that showed that DAPA measurements at $337 \mathrm{~nm}$ can also provide the second possible alternative UV detecting mode. Really, UV this monitoring produced only little smaller signals than the fluorescence emission signals obtained by the apply of the $337 \mathrm{~nm}$ excitation wavelength. Fortunately, as can be seen from elution profiles of duodenal digesta (Figure 1), the UV detection at $337 \mathrm{~nm}$ leads to significantly smaller changes of background levels in comparison with the UV monitoring at $230.7 \mathrm{~nm}$. Therefore, it is reasonable to expect that this UV detection mode can provides better separation of analytical DAPA peaks from the background fluctuations. Moreover, HPLC analysis of all assayed samples illustrated in Figure 1 reveal that separation of two DAPA peaks is best achieved by the use of the two UV detection modes in comparison with fluorescence emission obtained using the 231 and $337 \mathrm{~nm}$ excitation wavelength.

The response of DAPA was linearly related to the amount of DAPA within a wide range of DAPA content (from 0.017 to $0.510 \mu \mathrm{g}$ ) in the injected standards. The correlation coefficient ( $r$ ) and standards errors in slopes (SES) (Table 2) evidenced that better linearity of the calibration function, values of SES and precision of DAPA peaks integration offers UV monitoring at $337 \mathrm{~nm}$. Thus, these results evidenced that precision of DAPA quantification at longer wavelengths is better since the background fluctuations and levels on both sides of analytical DAPA peak is smaller in comparison with ones from UV detection at $230.7 \mathrm{~nm}$. Moreover, the lower values of LOD and LOQ (Table 2) based on UV monitoring at $337 \mathrm{~nm}$ are fully consistent with previously obtained results. Obviously, all values of LOD and LOQ for the two UV detection modes are low, therefore, the short and middle detections (i.e. at 230.7 and $337 \mathrm{~nm}$ ) are suitable for routine quantification of DAPA contents. Really, DAPA levels in assayed biological samples are greater $(>16 \mathrm{nmol} /$ $\mathrm{ml}$ ) in comparison with all obtained values of LOD and LOQ. The presented HPLC method with the UV detection at $337 \mathrm{~nm}$ (Table 2) offers significantly better sensi- 


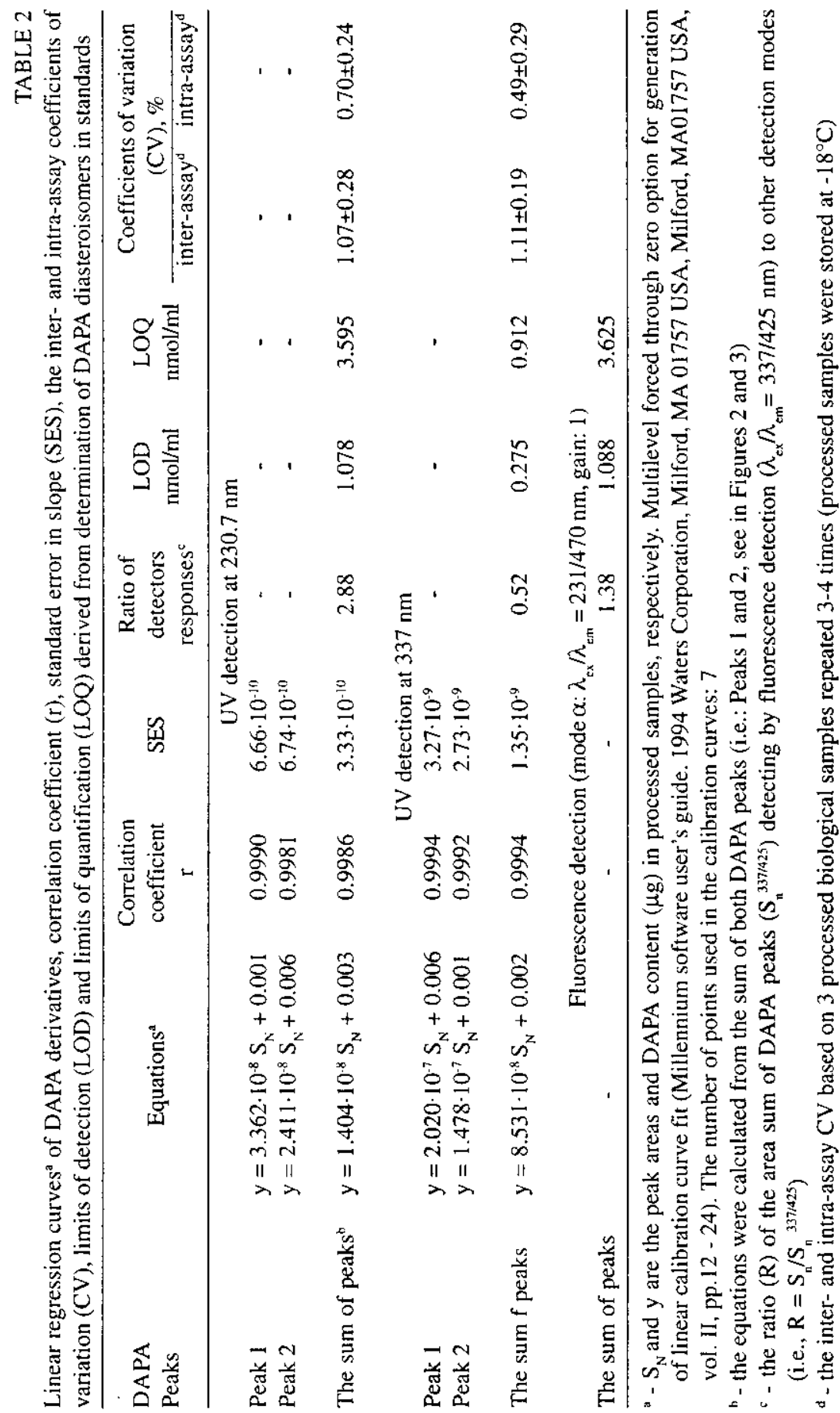




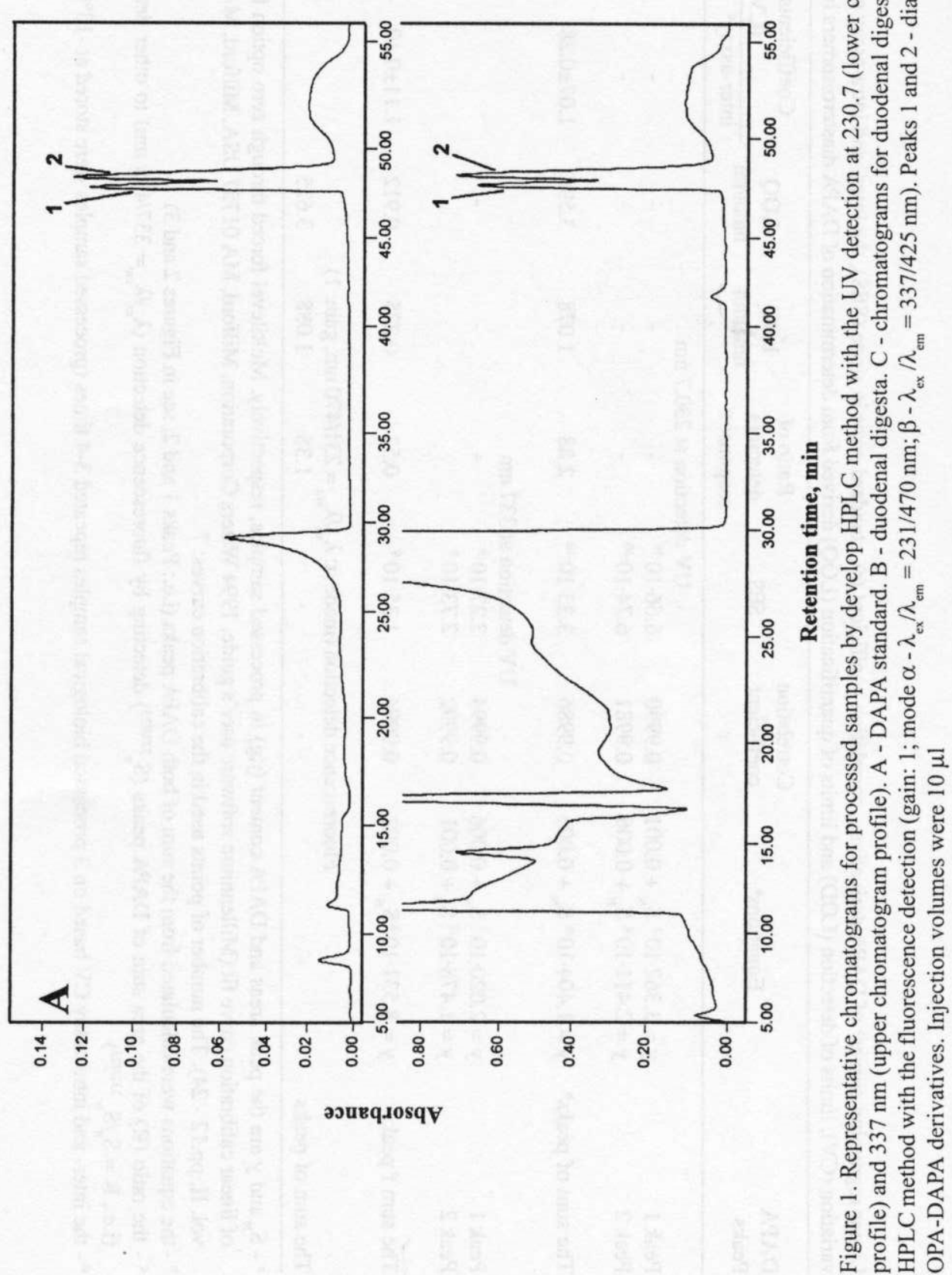




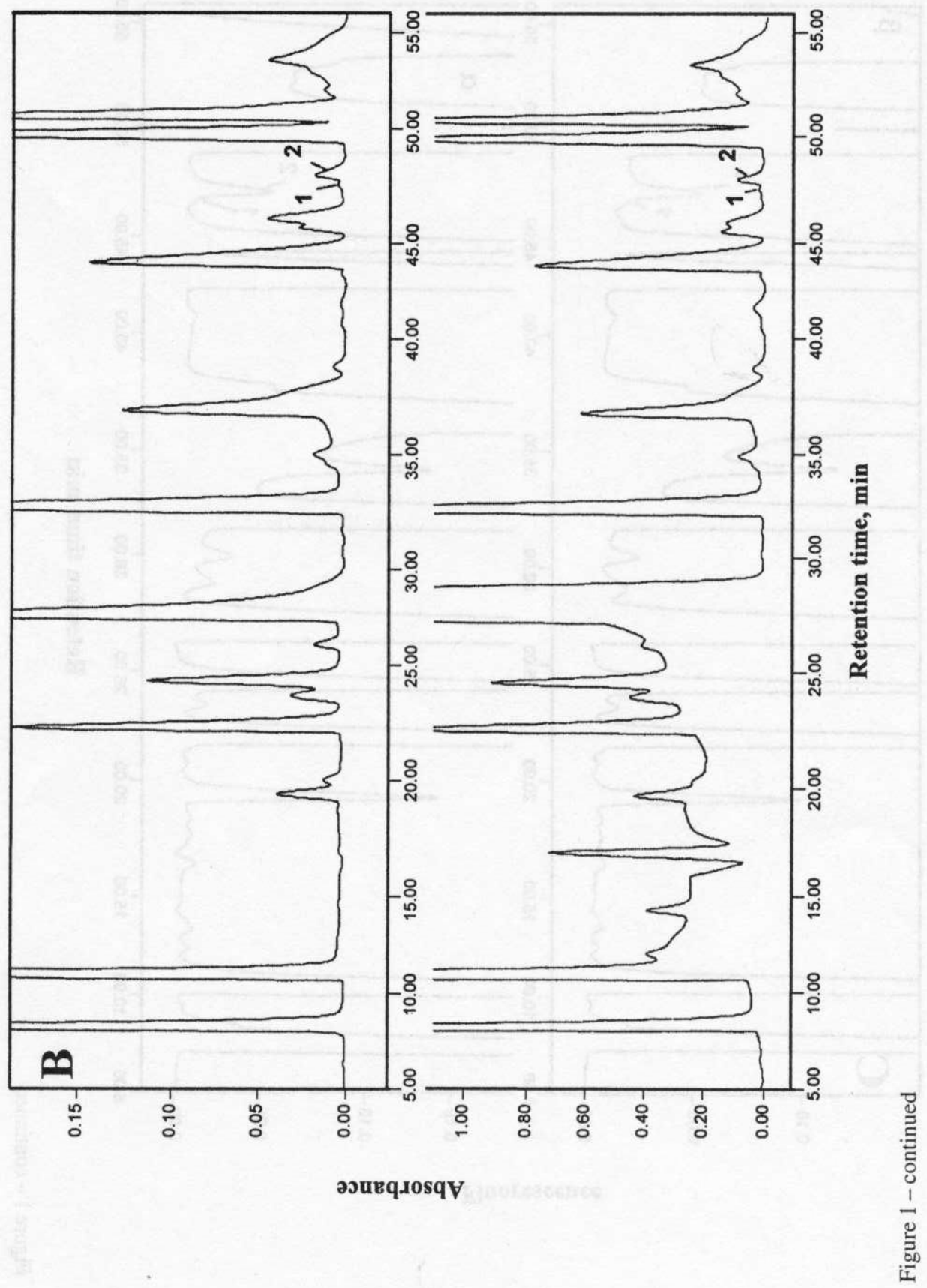




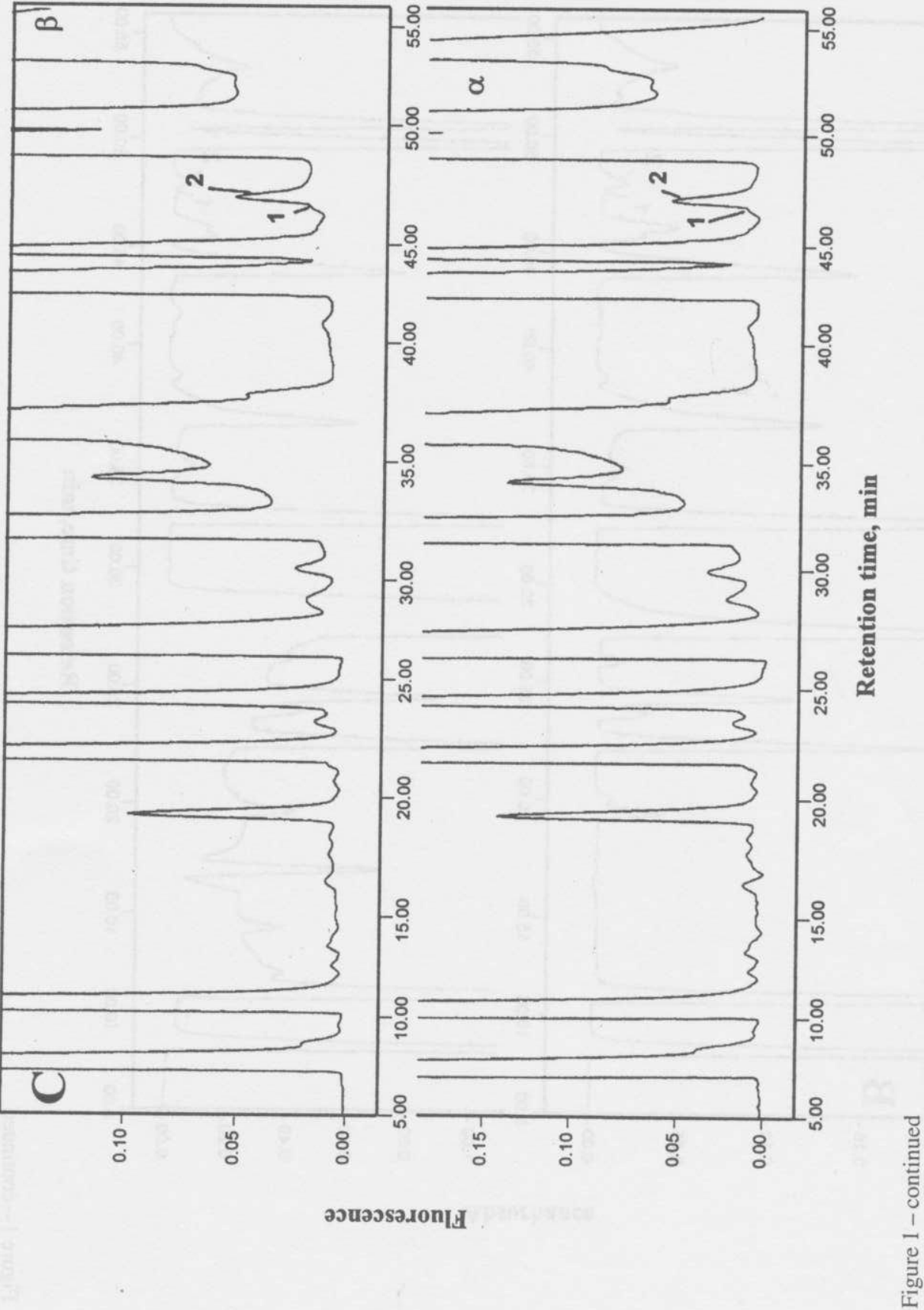


tivity than fluorescence detection obtained by the use of excitation at $231 \mathrm{~nm}$ and emission cut-off filter of $470 \mathrm{~nm}$, while the UV measurements at $230.7 \mathrm{~nm}$ gives only slightly better in comparison with this fluorescence detection.

\section{Reliability of HPLC method}

System reliability and reproducibility of the current HPLC method were evaluated by analyzing the inter- and intra-assay coefficients of variation $(\mathrm{CV}, \%)$ derived from the measurements of DAPA content in rumen bacteria and intestinal digesta. As can be seen from CV (Table 2), UV monitoring at 230.7 and $337 \mathrm{~nm}$ gives practically similar precision of the DAPA assays. The low values of intraand inter-assay $\mathrm{CV}$ indicate satisfactory precision and reproducibility of used HPLC system and applied derivatizing procedure.

Attempts were made to evaluate the accuracy of presented HPLC procedure by analyzing a recovery $(R, \%)$ of known quantities (i.e. $0.17,0.1$ and $0.05 \mu \mathrm{g}$ ) of DAPA added to rumen bacteria ( $35 \mu \mathrm{g}$ of lyophilized bacterial hydrolizate). The obtained average recoveries (number of replicates: 18) evidenced that the presented HPLC system provides good accuracy of DAPA assays, when the UV detections at 230.7 and $337 \mathrm{~nm}$ were applied (i.e. $\mathrm{R}=99.32 \pm 3.78$ and $99.00 \pm 4.25 \%$, respectively). The accuracy of the presented HPLC method was further assessed by fractionation of OPA-derivatives of seventeen amino acids standard mixture (protein hydrolysate, AssQ·Tag ${ }^{\mathrm{TM}}$, Waters) using developed HPLC system. As expected, no co-elution of DAPA peaks with examined mixture of amino acids was observed in the UV spectral range of $195-450 \mathrm{~nm}$. The accuracy of the presented method was also investigated by determining relationships between the UV detecting wavelength $\left(\lambda_{\mathrm{nm}}\right)$ and ratios $\left(\mathrm{R}^{\mathrm{nm}}\right)$ of area sum of DAPA peaks in all assayed biological samples ( $\left.\mathrm{R}_{\text {sampte }}^{\mathrm{nm}}\right)$ and a calibration standard ( $\left.\mathrm{R}^{\mathrm{nm}}{ }_{\text {standard }}\right)$ (i.e. $\mathrm{R}^{\mathrm{nm}}=\mathrm{R}_{\text {sample }}^{\mathrm{nm}} / \mathrm{R}^{\mathrm{nm}}$ standard for abbreviations see Table 3 ). As can be seen from data summarized in Table 3 all values of RSD were relatively small, as well as values of $\mathrm{R}^{\mathrm{nm}}$ average were practically equal to 1 . Considering the above mentioned results it is reasonable to conclude that peaks corresponding to DAPA in all assayed biological samples to be pure in the both examined UV ranges, i.e. devoid of interferences due to co-eluting peaks of endogenous species absorbing in the UV ranges applied. Obtained results evidenced that in the tested short and longer UV ranges, background fluctuations and the close presence of some unidentified species cannot interfere in the accurate integration of DAPA peaks.

The stability of DAPA derivative was detailed examined at $-18^{\circ} \mathrm{C}$ with respect to storage time of processed samples. Obtained results documented that an area of sum of DAPA peaks monitored at $230.7 \mathrm{~nm}$ was practically constant, when a processed sample was protected from the light and stored for 8 days at $-18^{\circ} \mathrm{C}$. Even after 20 days of storage, an area of sum of DAPA peaks decreased slightly 
TABLE 3

Relationships $\left(\mathrm{R}^{\mathrm{nn}}\right)^{\mathrm{u}}$ between the wavelength $\left(\lambda_{\mathrm{nm}}, \mathrm{nm}\right)$ of DAPA UV monitoring ${ }^{\mathrm{h}}$ and ratios of an area sum of DAPA peaks in standard $\left(\mathrm{R}_{\text {stantarmd }}^{\text {nim }}\right)^{\mathrm{c}}$ to an area sum of DAPA peaks in biological samples $\left(\mathrm{R}_{\text {sampie }}^{\mathrm{nnm}}\right)^{\mathrm{d}}$

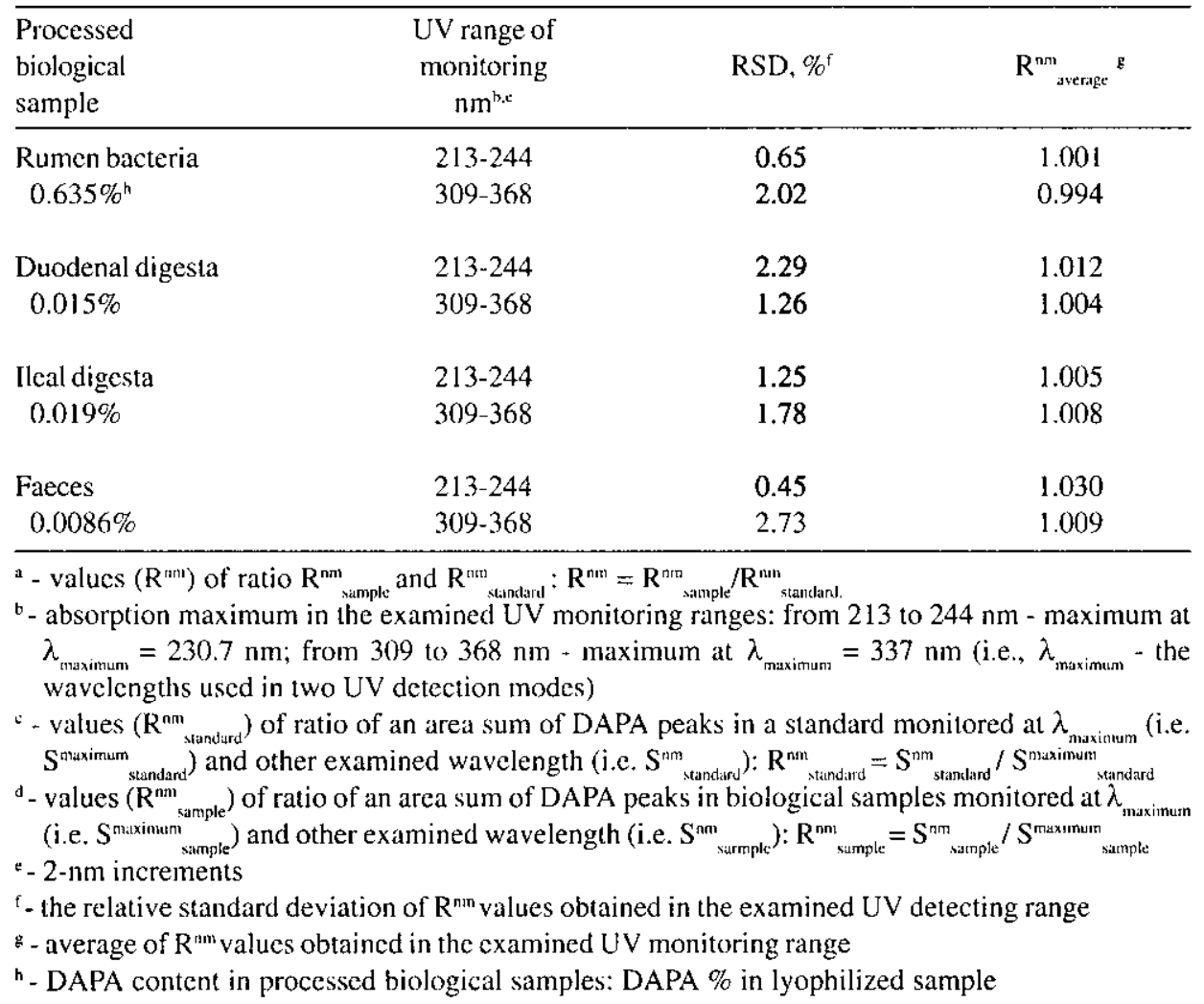

only ( $2.2 \%$ degradation). Thus, it seems clear from the UV detection at $230.7 \mathrm{~nm}$ that the DAPA derivative was practically stable at least for 8 days at $-18^{\circ} \mathrm{C}$, however, width of sum of DAPA peaks is smallest in only freshly derivatized solutions (i.e. after $3 \mathrm{~min}$ of the reaction time). Unexpectedly, the increase of an area of sum of DAPA peaks and width these peaks was observed after 3 min of the reaction time, when DAPA measurements were carried out by the use of the UV detection at $337 \mathrm{~nm}$. Considering the above results can be concluded that increase width of DAPA peaks reflected the changes in composition of formed DAPA derivatives. Really, during storage of the processed samples initially formed DAPA derivative is transformed into another DAPA derivatives (Molnar-Perl and Vasanits, 1999; Vasanits et al., 2000; Kutlan and Molnar-Perl, 2001; Molnar- 
Perl, 2001), thus, the reaction solutions contain mixture of DAPA derivatives having slightly different retention times and chromophoric group possessing a maximum absorbance at near $337 \mathrm{~nm}$.

\section{CONCLUSIONS}

The presented HPLC method enabled accurate, precise, reproducible and sensitive determination of DAPA in various types of biological samples. The use of the UV detection at 230.7 and $337 \mathrm{~nm}$ offers better sensitivity than the fluerescence detection. The HPLC system presented here was found to be more accurate, sensitive and selective than previously published methods (Czerkawski, 1974; MenginLecreulx et al., 1988; Webster et al., 1990; Puchała et al., 1992; Nagasawa et al., 1993; El-Waziry et al., 1996; Philipczyk et al., 1996; Czauderna et al., 1999; Czauderna and Kowalczyk, 1999; McKerrow et al., 2000) due to using high-efficiency long $\mathrm{C}_{18}$ column. The use UV detection assures higher method sensitivity than the fluorescence detection. Elimination of a special clean-up procedures yield our HPLC method a less expensive and time-consuming contrary to e.g., Webster method (Webster at el., 1990), and more versatile. The UV monitoring at $230.7 \mathrm{~nm}$ provided greatest response of detector as compared with other detection modes, so, we argued that the DAPA monitoring at $230.7 \mathrm{~nm}$ is most suitable for routine of DAPA assays in biological samples. Indeed, values of LOD and LOQ obtained by the use of this detection mode are considerably lower than DAPA concentration in these samples. A long and high resolution column $(25 \mathrm{~cm}, 3 \mu \mathrm{m})$ should be used because it enabled satisfactory separation of DAPA peaks from endogenous species present in processed biological samples. Consequently, the presented HPLC system with not specific detection mode but greatest DAPA response can be the possible alternative method for the estimation of bacterial protein production in ruminants and monitoring of bacterial contamination of examined samples.

\section{ACKNOWLEDGMENTS}

The technical assistance of MSc. G. Chojecki is gratefully acknowledged. 


\section{REFERENCES}

Buck R.H., Krummen K., 1987. High-performance liquid chromatographic determination of enantiomeric amino acids and amino alcohols after derivatisation with $o$-phthaldehyde and various chiral mercaptans. J. Chromatogr. 387, 255-265

Cockburn J.E., Williams A.P., 1984. The simultaneous estimation of the amounts of protozoal, bacterial and diatary nitrogen entering the duodenum of steers. Brit. J. Nutr. 51, 111-132

Cooper J.D.H., Ogden G., Mclntosh J., Turnell D.C., 1984. The stability of the $o$-phthal-alde-hyde/ 2-mercaptoethanol derivatives of amino acid: an investigation using high-pressure liquid chromatography with a precolumn derivatization technique. Anal. Biochem. 142, 98-102

Czauderna M., Kowaiczyk J., 1999. Determination of 2,6-diaminopimelic acid in bacteria, ruminal and duodenal digesta using HPLC with fluorescence or UV detection. J. Anim. Feed Sci. 8, 273 288

Czauderna M., Kowalczyk J., Kwiatkowska E., 1999. Determination of 2.6-diaminopimelic acid in rumen bacteria by various high-performance liquid chromatography method with pre-column derivatization. Chem. Anal. (Warsaw) 44, 243-255

Czerkawski J.W., 1974. Methods for determining 2-6-diaminopimelic acid and 2-aminoethylphosphonic acid in gut contents. J. Sci. Food. Agr. 24, 45-55

Djouvinov D.S., Todorov N.A., 1998. Estimation of microbial protein flow to the duodenum using different markers and of in vivo ruminal degradation of dietary purine bases in sheep fed hay and concentrate in different ratios. Bulgarian J. Agr. Sci. 4, 87-100

Edols R.W., 1985. Simple method for determination of diaminopimelic acid in rumen liquor hydrolysates. J. Chromatogr. 329, I99-201

El-Shazly K., Hungate R.E., 1966. Method for measuring diaminopimelic acid in total rumen contents and its application to the estimation of bacterial growth. J. Appl. Microbiol. 14, 27-30

El-Waziry A.M., Onodera R., 1996. In vitro metabolism of the stereoisomers of 2,6-diaminopimelic acid by mixed rumen protozoa and bacteria. Curr. Microbiol. 33, 306-311

El-Waziry A.M., Tomita Y., Ling J.R., Onodera R., 1996. Measurement of total and separate stereoisomers of diaminopimelic acid in rumen bacteria by high-performance liquid chromatography. J. Chromatogr. B 677, 53-59

Hill D.W., Walters F.H., Wilson T.D., Stuart J.D., 1979. High performance liquid chromatographic determination of amino acids in the picomole range. Anal. Chem. 51, 1338-1341

Hoshino S., Onodera R., Minato H., Itabashi H., 1990. The Rumen Ecosystem. The Microbial Metabolism and its Regulation. Japan Scientific Societies Press, Tokyo, p. 83

Kutlan D., Molnar-Perl I., 2001. Characteristics and stability of the OPA/3-mercaptopropionic acid and OPA/N-acetyl-L-cysteine derivatives of amino acids. Chromatographia 53, Suppl., S188S198

Lindroth P., Hamberger A., Sandberg M., 1999. Liquid chromatographic determination of amino acids after precolumn fluorescence derivatization. In: A.A. Boulton, G.B. Baker, J.D. Wood (Editors). Neuromethods, Vol. 3, Amino Acids. The Humana Press, Inc., pp. 97-116

Masson H.A., Denholm A.M., Ling J.R., 1991. In vivo metabolism of 2,2' -diaminopimelic acid from gram-positive and gram-negative bacterial cells by ruminal microorganisms and ruminants and its use as a marker of bacterial biomass. Appl. Environ. Microbiol. 57, 1714-1720

McKerrow J., Vagg S., McKinney T., Seviour E.M., Maszenan A.M., Brooks P., Seviour R. J., 2000. A simple HPLC method for analysing diaminopimelic acid diastereomers in cell walls of grampositive bacteria. Lett. Appl. Microbiol. 30, 178-182 
Mengin-Lecreulx D., Michaud C., Richaud C., Blanot D., Heijenoort J., 1988. Incorporation of LLdiaminopimelic acid into peptidoglycan of Escherichia coli mutants lacking diaminopimelate epimerase encoded by dapF. J. Bacteriol. 170, 2031-2039

Meyer V.R., 1999. Practical High-Performance Liquid Chromatography. John Wiley and Sons, Chichester (UK), p. 78

Molnar-Perl I., 2001. Derivatization and chromatographic behavior of the o-phthaldialdehyde amino acid derivatives obtained with various SH-group-containing additives. J. Chromatogr. A 913, 283-302

Molnar-Perl I., Vasanits A., 1999. Stability and characteristics of the 0 -phthaldialdehyde/3mercaptopropionic acid and $o$-phthaldialdehyde $/ N$-acetyl-L-cysteine reagents and their amino acid derivatives measured by high-performance liquid chromatography. J. Chromatogr. A 835 , 73-91

Nagasawa T., Ling J.R., Onodera R., 1993. Chiral high-performance liquid chromatographic separation of the three stereoisomers of 2.6-diaminopimelic acid without derivatisation. J. Chromatogr. A $653,336-340$

Philipczyk I.. Sudckum K.H., Ahrens F., Stangassinger M., 1996. Quantification of bacterial biomass in the rumen of steers with diaminopimelic acid as a marker: effects of forage stage of maturity, time of sampling and method of isolating the bacterial fraction. J. Anim. Physiol.. Anim. Nutr. 75, 105-119

Puchała R., Piór H., Kulasek G.W., 1992. Determination of diaminopimelic acid in biological materials using high-performance liquid chromatography. J. Chromatogr. 623, 63-67

Rattenbury J.M., 1981. Amino Acid Analysis, John Wiley and Sons, New York, pp. 37-47

Robinson P.H., Fadel J.G., Ivan M., 1996. Critical evaluation of diaminopimelic acid andribonucleic acid as markers to estimate rumen pools and duodenal flows of bacterial and protozoal nitrogen. Can. J. Anim. Sci. 76, 587-597

Sarwar G., Botting H.G., 1993. Evaluation of liquid chromatographic analysis of nutritionally important amino acids in food and physiological samples. J. Chromatogr. 615, 1-22

Vasanits A., Kutlan D., Sass P., Molnar-Perl I., 2000. Retention/quantitation properties of the $o$-phthaldialdehyde-3-mercaptopropionic acid and the $o$-phthaldialdehyde- $N$-acetyl-L-cysteine amino acid derivatives in reversed-phase high-performance liquid chromatography. J. Chromatogr. A $870,271-287$

Volker T., Wunsche J., Borgmann E., Souffrant W.-B., 1991. Estimation of 2,6-diaminopimelic acid in pig faeces and digesta. Arch. Anim. Nutr. 41, 615-621

Webster P.W., Hoover W.H., Miller T.K., 1990. Determination of 2,6-diaminopimelic acid in biological materials using high performance liquid chromatography. Anim. Feed Sci. Tech. 30, 11-20

Zhao G., Sasaki H., Kurosawa M., Sakai M., Nakashima Y., 1998. Measurement of undergradable grass hay ribonecleic acid by in sacco and in vivo methods and their effect on the estimation of microbial production in the rumen of sheep. Anim. Sci. Tech. 69, 146-153 


\section{STRESZCZENIE}

\section{Oznaczanie kwasu 2,6-diaminopimelinowego w bakteriach żwacza i treści jelit metodą HPLC z UV detekcją}

Opisano metodę HPLC oznaczania kwasu 2,6-diaminopimelinowego (DAPA) w próbkach bakterii żwacza, treści dwunastnicy, jelita biodrowego oraz kale. Po odparowaniu hydrolizatu DAPA przcprowadzano w pochodną używając o-dialdehyd ftalowy (OPA) w obecności etanotiolu. Pochodne diastereoizomerów DAPA rozdzielano na kolumnie $C_{18} z$ odwróconą fazą $(3 \mu \mathrm{m}, 250 \times 2,1 \mathrm{~mm}$ I.D., CPI, USA) poprzez elucję gradientową. Pochodną DAPA oznaczano stosując detekcję UV przy długości fali $\left(\lambda_{\text {del }}\right) 230,7 \mathrm{i} 337 \mathrm{~nm}$. Analiza chromatograficzna prowadziła do pojawienia się diastereoizomerów DAPA $w$ dwóch pikach o czasach retencji $46,77 \pm 0,20$ i 47,25 $\pm 0,21 \mathrm{~min}$. Całkowity czas analizy, wraz z kondycjonowaniem i równoważeniem kolumny, wynosił $60 \mathrm{~min}$. Średnia wartość odzysku standardu DAPA dodanego do próbek biologicznych wynosiła $99,32 \pm 3,78 \%\left(\lambda_{\mathrm{dct}}=230,7 \mathrm{~nm}\right)$ oraz $99,00 \pm 4,25 \%\left(\lambda_{\text {dee }}=337 \mathrm{~nm}\right)$. Prezentowana metoda jest zadowalająco precyzyjna, powtarzalna j dokładna, uzyskuje się bowiem niskie wartości współczynnika zmienności (CV, \%) oznaczania DAPA w obrębie przygotowania próbki i analizy HPLC $(\mathrm{CV} \approx 1,12 \%)$ oraz CV dla samej analizy HPLC (ok. 0,50\%). Stosując detekcję UV przy długości fali $337 \mathrm{~nm}$ otrzymuje się niższe wartości granicy detekcji jakościowej $\left(\mathrm{L}_{\mathrm{p}} \approx 0,28 \mathrm{nmol} / \mathrm{ml}\right)$ i ilościowej $\left(\mathrm{L}_{Q} \approx 0,91 \mathrm{nmol} / \mathrm{ml}\right)$ niż monitorowanie UV przy długości fali $230,7 \mathrm{~nm}$ lub stosując detekcję fluorescencyjną $\left(\mathrm{L}_{\mathrm{b}} \approx 1,1 \mathrm{nmol} / \mathrm{ml} ; \mathrm{L}_{\mathrm{O}} \approx 3,6\right.$ $\mathrm{nmol} / \mathrm{ml}$ ). Jednakże największe sygnały analityczne uzyskuje sį wykorzystując detekcję UV przy długości fali $230,7 \mathrm{~nm}$. Prezentowana metoda HPLC, wykorzystująca monitorowanie DAPA przy długości fali $230,7 \mathrm{~nm}$, może być z powodzeniem stosowana do określania rozmiaru syntezy białka bakteryjnego w żwaczu oraz do określania skażenia bakteryjnego materiałów biologicznych. 